\title{
Genomics of Aminoglycoside Resistance in Pseudomonas aeruginosa Bloodstream Infections at a United States Academic Hospital
}

Giancarlo Atassi, MPH ${ }^{1}$, Marc Scheetz, MSc ${ }^{2}$, Sophia Nozick ${ }^{3}$, Nathaniel J. Rhodes, MSc ${ }^{4}$, Megan Murphy-Belcaster ${ }^{3}$, Katherine R Murphy ${ }^{3 \#}$, Egon A. Ozer, MD, PhD ${ }^{5}$, Alan R. Hauser, $\mathrm{MD}, \mathrm{PhD}^{3,5^{*}}$

${ }^{1}$ Northwestern University Feinberg School of Medicine, Chicago, IL, USA

${ }^{2}$ Department of Pharmacy Practice, Pharmacometrics Center of Excellence, Chicago College of Pharmacy, Midwestern University, Downers Grove, IL, USA, Midwestern University, Downers Grove, IL, USA

${ }^{3}$ Department of Microbiology-Immunology, Northwestern University Feinberg School of Medicine, Chicago, IL, USA

${ }^{4}$ Pharmacometrics Center of Excellence, College of Graduate Studies, Department of Pharmacology, Midwestern University, Downers Grove, IL, USA

${ }^{5}$ Department of Medicine (Division of Infectious Diseases), Feinberg School of Medicine, Northwestern University, Chicago, IL, USA

\#Current address: Laboratories of Analytical Biology, National Museum of Natural History, Smithsonian Institution, Washington, D.C.

* CORRESPONDING AUTHOR: Alan Hauser, MD, PhD, Northwestern University Feinberg School of Medicine, Department of Microbiology/Immunology, 303 E Chicago Ave, Ward 6035, Chicago, IL 60611, ahauser@ northwestern.edu

WORD COUNT: 3810

FUNDING/CONFLICT(S) OF INTEREST: The authors report none. 


\begin{abstract}
Pseudomonas aeruginosa is a frequent cause of antibiotic-resistant infections. Although $P$. aeruginosa is intrinsically resistant to many antimicrobial agents, aminoglycosides are active against this organism in the absence of acquired resistance determinants and mutations. However, genes encoding aminoglycoside modifying enzymes (AMEs) are found in many strains that are resistant to these agents. We examined the prevalence of phenotypic resistance to the commonly used aminoglycosides gentamicin, tobramycin, and amikacin in a collection of 227 P. aeruginosa bloodstream isolates collected over two decades from a single U.S. academic medical institution. Resistance to these antibiotics was relatively stable over this time period. High-risk clones ST111 and ST298 were initially common but decreased in frequency over time. Whole genome sequencing identified relatively few AME genes in this collection compared to the published literature; only $14 \%$ of isolates contained an AME gene other than the ubiquitous $a p h(3$ ')-IIb. Of those present, only ant(2')-Ia was associated with phenotypic resistance to gentamicin or to tobramycin. One extensively drug-resistant strain, PS1871, contained 5 AME genes, most of which were part of clusters of antibiotic resistance genes embedded within transposable elements. These findings suggest that AME genes play a relatively minor role in aminoglycoside resistance at our institution but that multidrug-resistant strains remain a problem.
\end{abstract}




\section{Introduction}

Pseudomonas aeruginosa is a high-priority pathogen with a propensity for causing devastating opportunistic and nosocomial infections [1]. Complicating treatment of infections caused by this bacterium is significant intrinsic antimicrobial resistance (AMR) and a remarkable ability to mutate and acquire resistance determinants. As a result, many $P$. aeruginosa isolates are highly resistant to antibiotics, and a single strain may carry numerous antibiotic resistance genes [1-3]. Several of these multidrug resistant (MDR) and extensively drug-resistant (XDR) strains have disseminated globally and are referred to as "high-risk clones." Four major sequence types of these high-risk clones have been characterized over the past decade: ST111, ST175, ST235, and ST298 [1][4]. High-risk clones account for substantial proportions of multidrug-resistant $P$. aeruginosa isolates in some parts of the world and are a major healthcare threat.

Two approaches have been taken to address the challenge of antibiotic-resistant organisms such as $P$. aeruginosa. At the clinical level, antimicrobial stewardship programs are now required at medical institutions. Their role is to promote judicious and appropriate use of antimicrobial agents through evidence-based practice, and they have generally provided cost savings and decreased inappropriate antibiotic use and nosocomial infections by resistant pathogens without leading to increased mortality [5-8]. At the diagnostic level, molecular identification of resistance genes and alleles via nucleic-acid amplification or whole genome sequencing is being pursued to rapidly identify resistant and susceptible organisms and thus allow more focused antimicrobial therapy [9]. However, genomic resistance determinants can only provide surrogate markers of AMR and must be correlated to clinical phenotypes to validate their utility.

AMR genotype/phenotype correlation studies with $P$. aeruginosa have been challenging [10-12]. In particular, efforts directed at predicting aminoglycoside resistance have met with mixed success. P. aeruginosa deploys an array of resistance mechanisms against this class of antibiotics. Isolates can inactivate aminoglycosides via aminoglycoside modifying enzymes (AMEs), of which there are three primary families: phosphorylators (aph), acetylators (AAC), and adenylators (ant) $[13,14]$. Adding to this complexity is that individual AMEs have variable activities against the different aminoglycosides. $A A C(3), A A C\left(6^{\prime}\right)-I, A A C\left(6^{\prime}\right)-I I$, and ant (2'”) inactivate gentamicin; $A A C(3)-I I$, $\operatorname{ant}\left(2^{\prime \prime}\right)$, ant(4')-I, and $\operatorname{ant}\left(4^{\prime}\right)-I I$ inactivate tobramycin; $A A C\left(6^{\prime}\right)-I b, A A C(3)-X$, ant(4')-I, ant(4')-II, aph(3')-IIIa, and aph(3')-VIb inactivate amikacin. Other mechanisms of resistance include overexpression of efflux pumps (particularly the MexXY-OprM complex), modification of $16 \mathrm{~S}$ rRNA molecules by methylases such as $r m t A$ and $r m t B$ (rendering aminoglycosides unable to effectively bind ribosomes), and decreased permeability to aminoglycosides [14].

Here, we examined aminoglycoside resistance in $P$. aeruginosa bloodstream isolates at Northwestern Memorial Hospital (NMH) in Chicago, U.S. We examined changes in the prevalence of aminoglycoside resistance and the presence of AME genes over two decades and whether these genes predicted aminoglycoside resistance in these isolates. Finally, we determined the complete whole genome sequence of a MDR isolate carrying four distinct AME genes to examine the context of these resistance genes. 


\section{Materials and Methods}

\section{Antimicrobial Susceptibility Testing}

We obtained $P$. aeruginosa bloodstream isolates from three archived NMH collections cultured from 1999-2002, 2003-2009, and 2017-2019. All isolates were collected in accordance with and approval by the Northwestern University Institutional Review Board. Susceptibility testing was performed by broth microdilution for eight antibiotics (cefepime, ciprofloxacin, piperacillintazobactam, meropenem, colistin, amikacin, gentamicin, and tobramycin) as previously described [15], and susceptibility vs. nonsusceptibility (defined as resistant and intermediate classification) was determined using Clinical and Laboratory Standards Institute (CLSI) breakpoints [16]. For isolates not tested by broth microdilution, susceptibility results were generated by the NMH Clinical Microbiology Laboratory using the Vitek 2 platform (bioMérieux, Marcy l'Etoile, France).

\section{Whole genome sequencing}

The genome sequences of the 1999-2002 isolates were previously published [17][4, 18]. For the remaining isolates, bacteria were grown and underwent DNA extraction as previously described [17]. Library preparations were performed using the Nextera XT DNA Prep Kit (Illumina, Inc., San Diego, CA, USA) following the manufacturer's protocol. Short-read whole-genome sequencing was performed for all isolates using either the Illumina HiSeq or MiSeq platform to generate paired-end reads. Reads were trimmed using Trimmomatic (v0.36). Draft genomes were assembled from trimmed paired-end reads using SPAdes (v3.9.1). Draft genomes were further filtered to remove contigs shorter than $200 \square$ bp, with less than 5-fold mean read coverage, or with alignment to phiX. For PS1871, long-read sequencing was performed using the Nanopore MinION platform, and hybrid assembly with short-read Illumina sequences were performed as previously described [19]. Briefly, long-read sequencing libraries were prepared from unsheared genomic DNA using ligation sequencing kit SQK-LSK109 (Oxford Nanopore, UK) and sequenced on the MinION platform using a FLO-MIN106 flow cell. Guppy v3.4.5 was used to base call reads with the R9.4.1 high-accuracy model and to perform read quality filtering based on Q scores, demultiplexing, and barcode trimming. Assembly of nanopore reads was performed using Flye v2.8.1 to generate a single circularized contig [20]. Illumina reads were aligned to the assembly using BWA v0.7.17 [21], and assembly errors were corrected using Pilon v1.23 [22] with a minimum depth setting of 0.1 . Serial read alignment and Pilon correction were performed sequentially until no further assembly corrections were generated. Custom software (Pilon Tools v0.1; https://github.com/egonozer/pilon_tools) was used to identify, manually assess, and correct any residual homopolymer assembly errors. Accession numbers for all newly sequenced isolates are pending.

\section{Detection of antibiotic resistance genes}

Assembled libraries were submitted to the AMRFinderPlus tool (version 3.9.3, last accessed November 23, 2020) for detection of antimicrobial resistance genes and resistance-associated 
point mutations (Feldgarden et al., 2019) [23]. AMRFinderPlus is available from the National Center for Biotechnology Information (NCBI) at https://www.ncbi.nlm.nih.gov/pathogens/antimicrobial-resistance/AMRFinder/. The DDBJ Fast Annotation \& Submission Tool (DFAST; v.1.2.4, last accessed January $3^{\text {rd }}, 2021$ ) was used to annotate specific genomic features of the PS1871 chromosome [24]. SnapGene Viewer (from Insightful Science; available at snapgene.com) was used to generate linear chromosomal maps of the local regions of PS1871 surrounding AME genes found with AMRFinder, and the results from DFAST were used to annotate surrounding features.

\section{Determination of MLST genotype}

Each isolate's MLST was determined using ResFinder (v4.1, last accessed November 23, 2020; Center for Genomic Epidemiology) [25, 26]. ST111, ST175, ST235, and ST298 isolates were designated high-risk clones [1, 4]. MLSTs were assigned by ResFinder using PubMLST, an open-access curated database [27] that relies on a previously described MLST scheme for $P$. aeruginosa utilizing the seven housekeeping genes acsA, aroE, guaA, mutL, mutD, ppsA, and $\operatorname{trpE}[28]$.

\section{Statistical Analysis}

Changes in antibiotic susceptibility rates over time and changes in the number of isolates with at least one AME gene across each of the three time periods were analyzed using Chi-Square tests of linear trend to determine whether there was a significant trend across the different time periods. All Chi-Square tests of trend were performed in EpiInfo 7.2.4.0 (Centers for Disease Control \& Prevention, Atlanta, GA). The remainder of the statistics were performed in Stata IC 16.1 (Statacorp LLC, College Station, TX). For phenotypic aminoglycoside resistance predictions based on the presence of single AME genes, logistic regressions were performed using the presence of each individual AME gene. The presence of at least one member of gene groups were also considered; AME genes were grouped based on their activities against a specific aminoglycoside. A gentamicin group was comprised of the following AME genes: $A A C(3), A A C(6)-I, A A C(6)-I I$, or ant(2”). Initially, a tobramycin group comprised of ant(2”), $A A C(3)$, ant(4)-I, or ant(4)-II was also planned. However, only one of these tobramycin-active genes (ant (2”)-Ia) was found in our collection, so we did not perform this analysis. Logistic regression was completed with the gentamicin-active gene group for predicting categorical resistance and was performed in stepwise fashion with $\mathrm{P}<0.2$ used for removal from the model. Results are reported from the final model in the form of odds ratios with confidence intervals and p-values.

\section{Results}

\section{Changes in Aminoglycoside Resistance of Pseudomonas aeruginosa Over Time at NMH}

We examined aminoglycoside resistance in a total of 227 archived $P$. aeruginosa bloodstream isolates from three time periods: 93 from 1999-2002, 101 from 2003-2009, and 33 from 20172019. Susceptibility rates to gentamicin, tobramycin, and amikacin were measured. 
Susceptibility rates to amikacin were highest and remained stable across these time periods, ranging from $92-94 \%$ (Figure 1). Susceptibility rates to tobramycin were somewhat lower (85$87 \%$ ) but also remained stable. In contrast, susceptibility rates to gentamicin were lower still and more variable. They were $73 \%$ in $1999-2002,87 \%$ in $2003-2009$, and then $76 \%$ in $2017-2019$ (Chi-Square test of linear trend, $\chi=1.971, \mathrm{p}=0.160$ ). We compared these susceptibility rates to those of five other commonly used antipseudomonal antibiotics: piperacillin-tazobactam, cefepime, meropenem, ciprofloxacin, and colistin. For each of these except colistin, susceptibility rates had not undergone a statistically significant change across the three time periods (Figure 1). Susceptibility rates were lowest for ciprofloxacin, for which only 57-70\% of isolates were susceptible. For colistin, susceptibility rates were $92 \%$ in the first cohort, decreased to $69 \%$ in the second cohort, and then increased to $82 \%$ in the third cohort (Chi-Square test of linear trend, $\chi=11.799, \mathrm{p}<0.001)$. These results suggest that $P$. aeruginosa isolates at $\mathrm{NMH}$ have remained relatively susceptible to amikacin and tobramycin but that susceptibility rates to gentamicin have been more variable.

\section{Prevalence and Changes in Multilocus Sequence Types over Time at NMH}

High-risk clones are responsible for a substantial proportion of antibiotic resistance, including aminoglycoside resistance, in P. aeruginosa, but little is known about whether these clones are increasing or decreasing in prevalence. We therefore analyzed the MLSTs of each isolate for the presence of high-risk clone STs. Existing MLSTs were identified for 209 of the 227 isolates. The remaining 18 isolates had exact identity matches for all seven housekeeping genes but did not correspond to known MLSTs, indicating that they represent new STs. Of the 93 isolates from 1999-2002, the most common MLSTs were ST298 (8 isolates; 8.6\%), ST348 (8 isolates; 8.6\%), ST111 (6 isolates; 6.5\%), ST639 (5 isolates; 5.4\%), and ST2613 (4 isolates; 4.3\%). From 20032009, of 101 isolates, the most common were ST639 (8 isolates; 7.9\%), ST2613 (5 isolates; 4.9\%), ST471 (5 isolates; 4.9\%), ST298 (4 isolates; 3.9\%), and ST111 (4 isolates; 3.9\%). From 2017-2019, the most common were ST252 (3 isolates; 9.1\%), ST646 (3 isolates; 9.1\%), ST27 (2 isolates; 6.1\%), and ST532 (2 isolates; 6.1\%). Of these STs, two (ST111 and ST298) have been reported as high-risk clones. (ST175 and ST235, the other two well characterized high-risk clones, were not found in our cohorts). The cumulative prevalence of high-risk clones therefore decreased from 14 of 93 isolates (15\%) in 1999-2002 to 1 of 33 isolates (0.30\%) in 2017-2019 (Chi-Square test of linear trend, $\chi=4.757, \mathrm{p}=0.029$ ). These findings demonstrate that high-risk clones have been circulating at NMH but may be decreasing in prevalence.

\section{Presence of Aminoglycoside Modifying Enzyme Genes in P. aeruginosa Isolates}

We next examined the whole genome sequences of each isolate for aminoglycoside modifying enzyme (AME) and methylase genes (Table 2). Except for $a p h\left(3^{\prime}\right)-I I b$, which was found in all isolates, AME genes were relatively rare. $\operatorname{ant}(2$ ")-Ia was the most common AME gene in the 1999-2002 cohort, followed by several aadA genes (members of the $\operatorname{ant}(3$ ”) family). In the 
2003-2009 cohort, the most common AME gene was aadA6, and ant(2")-Ia was still fairly prevalent. In the 2017-2019 cohort, only genes from the ant family (aadA6, aadA10, ant(2”)-Ia) were present, perhaps due to the smaller size of this collection. None of the cohorts contained isolates with the $r m t A$ or $r m t B$ methylase genes. Excluding $a p h\left(3^{\prime}\right)-I I b$, the prevalence of isolates with at least one AME gene decreased from 16 of 93 isolates (17.2\%) in the 1999-2002 cohort to 14 of 101 isolates $(13.8 \%)$ in the 2003-2009 cohort to 2 of 33 isolates $(6.1 \%)$ in the 2017-2019 cohort. These differences were not statistically significant (Chi-Square test of linear trend, $\chi=$ 2.292, $\mathrm{p}=0.130)$.

\section{Associations Between Aminoglycoside Resistance and Presence of AME Genes}

We next examined whether individual AME genes as well as combinations of AME genes predicted phenotypic resistance to aminoglycosides. We focused on gentamicin and tobramycin because only four AME genes targeting amikacin were present in our collections. For gentamicin and tobramycin, we individually examined each of the AME genes but found that only ant(2”)Ia showed a statistically significant association with resistance to gentamicin (OR 4.03 [1.02, 15.84], $\mathrm{p}=0.046$ ) or tobramycin (OR 5.06 [1.32, 19.51], $\mathrm{p}=0.018)$. A statistically significant association was not found between phenotypic resistance and the presence of at least one AME gene with predicted activity against either gentamicin (OR $2.53[0.88,7.28], \mathrm{p}=0.084)$. (A similar grouped analysis was not performed for tobramycin because ant( 2 ”)-Ia was the only AME gene in our collection with predicted activity against this antibiotic.) These results suggest that AME genes play a relatively minor role in causing gentamicin and tobramycin phenotypic resistance in $P$. aeruginosa at $\mathrm{NMH}$.

\section{Genomic Characterization of an Isolate with Multiple AMEs}

We next more closely examined the distribution of AME genes in our collection of isolates. As mentioned earlier, all isolates contained the $a p h\left(3^{\prime}\right)$-IIb gene, but most isolates did not contain additional AME genes. One exception was PS1871, an XDR isolate (nonsusceptible to piperacillin-tazobactam, cefepime, meropenem, ciprofloxacin, tobramycin, and gentamicin) that was noted to have a total of five AME genes (aph(3')-IIb, AAC(6')-Ib, ant(2')-Ia, and two copies of aadA1). PS1871 had the following MICs to aminoglycosides: $16 \mu \mathrm{g} / \mathrm{mL}$ for amikacin (susceptible), $16 \mu \mathrm{g} / \mathrm{mL}$ for tobramycin (nonsusceptible), and $16 \mu \mathrm{g} / \mathrm{mL}$ for gentamicin (nonsusceptible).

To further characterize PS1871, we performed long-read sequencing and combined these results with the previously obtained short-read sequencing results to obtain its complete genome. This genome was used to identify the locations of the AME genes (Figure 2). $\operatorname{ant}(2$ ”)-Ia and aadA are located among a cluster of transposon genes, alongside qacE (encoding an efflux pump associated with antiseptic resistance). $A A C\left(6^{\prime}\right)-I b$ and a second copy of aadA are located adjacent to two $\beta$-lactamase genes, $O X A-9$ and TEM-1, and near a different copy of $q a c E$ as well as $d f r A 1$, a trimethoprim-resistance-conferring dihydrofolate reductase. These genes are also 
medRxiv preprint doi: https://doi.org/10.1101/2021.01.15.21249897; this version posted January 20, 2021. The copyright holder for this preprint (which was not certified by peer review) is the author/funder, who has granted medRxiv a license to display the preprint in perpetuity. It is made available under a CC-BY-NC-ND 4.0 International license .

associated with a large transposon complex. Finally, $a p h\left(3^{\prime}\right)-I I b$ was located in a distinct region of the chromosome and was not adjacent to known AMR or transposase genes.

\section{Discussion}

In this study, we examined changes in aminoglycoside resistance rates in $P$. aeruginosa over time at our institution. We focused on bloodstream isolates and found that susceptibility rates were relatively stable from 1999 to 2019. Similar trends were observed with several other commonly used antipseudomonal antibiotics. An exception was colistin, for which nonsusceptibility rates varied substantially over time. These results should be considered in the context of several trends. An increasing prevalence of MDR and XDR P. aeruginosa isolates has been frequently reported, with rates of drug-resistant strains between $15 \%$ and $30 \%$ in some areas [29][30]. For example, Yayan et al. (2015) noted a significant increase in the prevalence of MDR isolates in a sample of 168 P. aeruginosa pneumonia isolates from 2004-2014 [31]. On the other hand, the CDC has estimated that antimicrobial stewardship efforts have led to a $29 \%$ drop in MDR P. aeruginosa infections in the U.S. between 2012 and 2017 [32]. Consistent with this, Abbara et al. (2019) studied the before (2007-2010) and after (2011-2014) period of an antimicrobial stewardship program intervention and found significant improvements in antibiotic usage, as well as dramatic decreases in $P$. aeruginosa resistance rates, including a drop in resistance to amikacin from $30.9 \%$ to $0.8 \%$ [33]. The antibiotic stewardship program at NMH began in the 1990s but was substantially enhanced in 2006, when it formally received funding for the administrative effort of a physician. A third potential factor influencing antibiotic resistance rates are infection control and prevention efforts. In our study, the decreased prevalence over time of high-risk clones, which are thought to be transmitted from patient to patient, could reflect the increasing success of these efforts. Antibiotic resistance is influenced by a complex set of factors, and the reasons contributing to relatively stable rates at our hospital require further study.

Our genomic analyses indicated that AME genes are relatively rare at $\mathrm{NMH}$. The only exception was $a p h$ (3')-IIb, which provides intrinsic resistance to kanamycin, neomycin, butirocin, and seldomycin, though not the clinically relevant aminoglycosides gentamicin, tobramycin, or amikacin [34]. In agreement with prior reports showing that $a p h\left(3^{\prime}\right)-I I b$ is present in nearly all $P$. aeruginosa bacteria [34], we found this chromosomal aminoglycoside phosphotransferase in every isolate in our collection. Other relatively common AME genes were ant(2")-Ia (5.7\% of isolates), aadA6 (4.4\% of isolates), and aadA10 (3.5\% of isolates). Notably, aadA AMEs are members of the ant (3") family of nucleotidyltransferases, which are the most common ant AME genes and are typically found in integrons, plasmids and transposons. These AMEs primarily confer resistance to spectinomycin and streptomycin, but not gentamicin, tobramycin, or amikacin [14]. Excluding the ubiquitous $a p h\left(3^{\prime}\right)-I I b$, the overall prevalence of isolates containing AME genes was 14\%, less than that reported in several published studies. A French study of 120 P. aeruginosa bacteremia isolates collected between 1999 and 2004 showed that 25 (21\%) of them contained one or more genes encoding for the AMEs ant(2”)-I, AAC(6')-I, and $A A C(3)-I$ [35]. In northeastern Poland, a study of 25 P. aeruginosa samples collected from two intensive care units between 2002-2009 detected ant(2')- $I a$ in 36\%, AAC(6')-Ib in 28\%, and 
medRxiv preprint doi: https://doi.org/10.1101/2021.01.15.21249897; this version posted January 20, 2021. The copyright holder for this preprint (which was not certified by peer review) is the author/funder, who has granted medRxiv a license to display the preprint in perpetuity. It is made available under a CC-BY-NC-ND 4.0 International license .

$a p h\left(3^{\prime}\right)-I b$ in $8 \%$ of the isolates [36]. Holbrook \& Tsodikova (2018) studied 122 MDR $P$. aeruginosa isolates from the University of Kentucky Health System and found that $41 \%$ carried $A A C\left(6^{\prime}\right)-I b, 11 \%$ carried $A A C(3)-I V, 6 \%$ carried $\operatorname{ant}\left(2^{\prime \prime}\right)$ - Ia, and 71\% carried $\operatorname{aph}\left(3^{\prime}\right)$ - Ia [37]. In Venezuela, a study of 137 P. aeruginosa isolates collected from clinical samples during 20102011 found that 49 isolates were resistant to at least one of the following aminoglycosides: gentamicin, amikacin, netilmicin, and tobramycin. Within those 49, 39 had at least one AME gene detected. The most commonly detected AME genes were $A A C\left(6^{\prime}\right)-I b, a p h A 1, a a d B$, aphA2, and $A A C\left(3^{\prime}\right)$-IIa [38]. There are several potential explanations for the differences between our results and these published studies. The results cited above are from different geographical locations than $\mathrm{NMH}$, and AME gene prevalence may differ from region to region. In addition, the cited reports examined different types of isolates collections, including specific collections of MDR isolates, ICU isolates, or non-bloodstream isolates.

Several groups have predicted aminoglycoside resistance in bacteria other than P. aeruginosa based upon the presence or absence of AME genes [41]. Stoesser et al. (2013) compared phenotypes of resistance for E. coli and Klebsiella pneumoniae with genotypic predictions of resistance, and noted $96 \%$ sensitivity and $100 \%$ specificity for gentamicin [39]. Sadouki et al. (2017) compared phenotypic and genotypic resistance for ten antibiotics against Shigella sonnei and found only fifteen $(0.45 \%)$ discordances across 3,350 isolate/antimicrobial class combinations. Only 7 of 335 isolates were resistant to gentamicin, and each of the 7 possessed either $A A C(3)-I I d$ or $A A C(3)-I V a$, which confer gentamicin resistance [40].

Attempts to predict aminoglycoside phenotypes from genotypes have been less successful in $P$. aeruginosa than in other bacteria. Several reports examining only one or two isolates have noted correlations. For example, de Oliveria Santos et al. (2018) reported an isolate that was phenotypically susceptible to gentamicin and resistant to amikacin, and it carried $a p h\left(3^{\prime}\right)-I I b$ and $\operatorname{aph}\left(3^{\prime}\right)-V I$, which confer resistance to amikacin but not gentamicin [42]. Kocsis et al. (2019) examined a $P$. aeruginosa ST773 isolate and found $r m t B$, a 16S rRNA methylase, concordant with the isolate's significant tobramycin resistance [43]. Madaha et al. (2020) looked at a pair of multidrug resistant $P$. aeruginosa strains and found that one was pan-susceptible to aminoglycosides, harboring only $a p h\left(3^{\prime}\right)-I I b$, while the other, which harbored $r m t B$ and several other AME genes, was pan-resistant to aminoglycosides [44]. Examination of larger collections of isolates, however, have not observed these associations. Freschi et al. (2018) examined $33 P$. aeruginosa isolates acquired from cystic fibrosis $(\mathrm{CF})$ patients and seven reference genomes. They found poor correlations between genetic resistomes and phenotypic susceptibilities, noting that only for fluoroquinolones were correlations observed [45]. Jeukens et al. (2017) analyzed genetic resistomes and correlated them to resistance phenotypes in seven isolates. Only one was resistant to aminoglycosides, and this isolate harbored no identified resistance determinants apart from $a p h\left(3^{\prime}\right)-I I b$. These findings underscore the difficulties in linking the presence of AME genes to phenotypic aminoglycoside resistance in $P$. aeruginosa.

In this study, our ability to successfully predict aminoglycoside resistance phenotypes from the presence of AME genes was limited. This may be due to the multiple mechanisms that can account for aminoglycoside resistance in $P$. aeruginosa. In addition to AMEs and methylases, $P$. 
aeruginosa is capable of increased aminoglycoside efflux and impermeability [1, 46]. A limitation of our study is that these other mechanisms were not assessed. Likewise, we did not measure expression of AME genes, and it is possible that some of these genes were "silent." Broader experimental and genomic studies will be necessary to better predict aminoglycoside phenotypes from $P$. aeruginosa genomes.

We examined in detail the genome of one XDR isolate, PS1871. We found that of the five AME genes present in this isolate, four occurred in pairs, and each pair was found in the context of multiple transposon genes. Additionally, both pairs were near a qacE efflux pump gene, and one pair was located next to $\beta$-lactamase genes $O X A-9$ and TEM-1. These findings suggest that these four AME genes are capable of being transferred by horizontal transfer of genetic elements and that this process may be driven by exposure to antibiotics and disinfectants.

Our findings suggest that resistance to aminoglycosides remains relatively stable and uncommon at our hospital and is largely driven by mechanisms other than AME genes. However, XDR strains such as PS1871 may harbor multiple AME genes, and ongoing vigilance is required to prevent their spread.

\section{ACKNOWLEDGEMENTS}

The project was funded by the National Institutes of Health: R01AI118257, U19AI135964, K24AI04831, and R21AI129167 (all to A.R.H.). 
medRxiv preprint doi: https://doi.org/10.1101/2021.01.15.21249897; this version posted January 20, 2021. The copyright holder for this preprint (which was not certified by peer review) is the author/funder, who has granted medRxiv a license to display the preprint in perpetuity.

It is made available under a CC-BY-NC-ND 4.0 International license .

\section{BIBLIOGRAPHY}

[1] Oliver A, Mulet X, López-Causapé C, Juan C. The increasing threat of Pseudomonas aeruginosa high-risk clones. Drug Resist Updat. 2015 Jul-Aug;21-22:41-59. doi:

10.1016/j.drup.2015.08.002. Epub 2015 Aug 10. PMID: 26304792.

[2] Treepong P, Kos VN, Guyeux C, Blanc DS, Bertrand X, Valot B, Hocquet D. Global emergence of the widespread Pseudomonas aeruginosa ST235 clone. Clin Microbiol Infect. 2018 Mar;24(3):258-266. doi: 10.1016/j.cmi.2017.06.018. Epub 2017 Jun 23. PMID: 28648860.

[3] Mathers AJ, Peirano G, Pitout JD. The role of epidemic resistance plasmids and international high-risk clones in the spread of multidrug-resistant Enterobacteriaceae. Clin Microbiol Rev. 2015 Jul;28(3):565-91. doi: 10.1128/CMR.00116-14. PMID: 25926236; PMCID: PMC4405625.

[4] Pincus NB, Bachta KER, Ozer EA, et al. Long-term Persistence of an Extensively DrugResistant Subclade of Globally Distributed Pseudomonas aeruginosa Clonal Complex 446 in an Academic Medical Center. Clin Infect Dis. 2020;71(6):1524-1531. doi:10.1093/cid/ciz973

[5] Rice LB. Antimicrobial Stewardship and Antimicrobial Resistance. Med Clin North Am. 2018 Sep;102(5):805-818. doi: 10.1016/j.mcna.2018.04.004. Epub 2018 Jul 14. PMID: 30126572.

[6] Lindsay PJ, Rohailla S, Taggart LR, Lightfoot D, Havey T, Daneman N, Lowe C, Muller MP. Antimicrobial Stewardship and Intensive Care Unit Mortality: A Systematic Review. Clin Infect Dis. 2019 Feb 15;68(5):748-756. doi: 10.1093/cid/ciy550. PMID: 29982376.

[7] Horikoshi Y, Suwa J, Higuchi H, Kaneko T, Furuichi M, Aizawa Y, Fukuoka K, Okazaki K, Ito K, Shoji T. Sustained pediatric antimicrobial stewardship program with consultation to infectious diseases reduced carbapenem resistance and infection-related mortality. Int J Infect Dis. 2017 Nov;64:69-73. doi: 10.1016/j.ijid.2017.09.012. Epub 2017 Sep 21. PMID: 28941633.

[8] Nathwani D, Varghese D, Stephens J, Ansari W, Martin S, Charbonneau C. Value of hospital antimicrobial stewardship programs [ASPs]: a systematic review. Antimicrob Resist Infect Control. 2019 Feb 12;8:35. doi: 10.1186/s13756-019-0471-0. PMID: 30805182; PMCID: PMC6373132.

[9] van Belkum, A., Burnham, CA.D., Rossen, J.W.A. et al. Innovative and rapid antimicrobial susceptibility testing systems. Nat Rev Microbiol 18, 299-311 (2020).

https://doi.org/10.1038/s41579-020-0327-x

[10] Kos VN, Déraspe M, McLaughlin RE, et al. The resistome of Pseudomonas aeruginosa in relationship to phenotypic susceptibility. Antimicrob Agents Chemother. 2015;59(1):427-436. doi:10.1128/AAC.03954-14

[11] Jaillard M, van Belkum A, Cady KC, Creely D, Shortridge D, Blanc B, Barbu EM, Dunne WM Jr, Zambardi G, Enright M, Mugnier N, Le Priol C, Schicklin S, Guigon G, Veyrieras JB. Correlation between phenotypic antibiotic susceptibility and the resistome in Pseudomonas 
medRxiv preprint doi: https://doi.org/10.1101/2021.01.15.21249897; this version posted January 20, 2021. The copyright holder for this preprint (which was not certified by peer review) is the author/funder, who has granted medRxiv a license to display the preprint in perpetuity. It is made available under a CC-BY-NC-ND 4.0 International license .

aeruginosa. Int J Antimicrob Agents. 2017 Aug;50(2):210-218. doi:

10.1016/j.ijantimicag.2017.02.026. Epub 2017 May 26. PMID: 28554735.

[12] Jeukens J, Kukavica-Ibrulj I, Emond-Rheault JG, Freschi L, Levesque RC. Comparative genomics of a drug-resistant Pseudomonas aeruginosa panel and the challenges of antimicrobial resistance prediction from genomes. FEMS Microbiol Lett. 2017 Oct 2;364(18). doi: 10.1093/femsle/fnx161. PMID: 28922838.

[13] Poole K. Aminoglycoside Resistance in Pseudomonas aeruginosa. Antimicrob Agents Chemother. 2005;49(2):479-487. DOI: 10.1128/AAC.49.2.479-487.2005

[14] Ramirez MS, Tolmasky ME. Aminoglycoside modifying enzymes. Drug Resist Updat. 2010;13(6):151 $\square$ 171. doi:10.1016/j.drup.2010.08.003

[15] Wiegand, I., Hilpert, K. \& Hancock, R. E. Agar and broth dilution methods to determine the minimal inhibitory concentration (Mic) of antimicrobial substances. Nat. Protoc. 3, 163-175 (2008).

[16] CLSI. 2020 Performance Standards for Antimicrobial Susceptibility Testing. 30th Edition. CLSI Guideline M100-ED30. Wayne, PA: Clinical and Laboratory Standards Institute; 2020.

[17] Allen JP, Ozer EA, Minasov G, Shuvalova L, Kiryukhina O, Satchell KJF, Hauser AR. A comparative genomics approach identifies contact-dependent growth inhibition as a virulence determinant. Proc Natl Acad Sci U S A. 2020 Mar 24;117(12):6811-6821. doi:

10.1073/pnas.1919198117. Epub 2020 Mar 10. Erratum in: Proc Natl Acad Sci U S A. 2020 May 19;117(20):11184. Erratum in: Proc Natl Acad Sci U S A. 2020 Dec 8;117(49):31553. PMID: 32156726; PMCID: PMC7104216.

[18] Bachta, K.E.R., Allen, J.P., Cheung, B.H. et al. Systemic infection facilitates transmission of Pseudomonas aeruginosa in mice. Nat Commun 11, 543 (2020).

https://doi.org/10.1038/s41467-020-14363-4

[19] Cherny KE, Ozer EA, Kochan TJ, Kociolek LK. Complete Genome Sequence of Clostridium innocuum Strain ATCC 14501. Microbiol Resour Announc. 2020 Jul 23;9(30):e00452-20. doi: 10.1128/MRA.00452-20. PMID: 32703829; PMCID: PMC7378028.

[20] Kolmogorov M, Yuan J, Lin Y, Pevzner PA. Assembly of long, error-prone reads using repeat graphs. Nat Biotechnol. 2019 May;37(5):540-546. doi: 10.1038/s41587-019-0072-8. Epub 2019 Apr 1. PMID: 30936562.

[21] Li H, Durbin R. Fast and accurate short read alignment with Burrows-Wheeler transform. Bioinformatics. 2009 Jul 15;25(14):1754-60. doi: 10.1093/bioinformatics/btp324. Epub 2009 May 18. PMID: 19451168; PMCID: PMC2705234.

[22] Walker BJ, Abeel T, Shea T, Priest M, Abouelliel A, Sakthikumar S, Cuomo CA, Zeng Q, Wortman J, Young SK, Earl AM. Pilon: an integrated tool for comprehensive microbial variant detection and genome assembly improvement. PLoS One. 2014 Nov 19;9(11):e112963. doi: 10.1371/journal.pone.0112963. PMID: 25409509; PMCID: PMC4237348. 
[23] Feldgarden M, Brover V, Haft DH, Prasad AB, Slotta DJ, Tolstoy I, Tyson GH, Zhao S, Hsu CH, McDermott PF, Tadesse DA, Morales C, Simmons M, Tillman G, Wasilenko J, Folster JP, Klimke W. Validating the AMRFinder Tool and Resistance Gene Database by Using Antimicrobial Resistance Genotype-Phenotype Correlations in a Collection of Isolates. Antimicrob Agents Chemother. 2019 Oct 22;63(11):e00483-19. doi: 10.1128/AAC.00483-19. Erratum in: Antimicrob Agents Chemother. 2020 Mar 24;64(4): PMID: 31427293; PMCID: PMC6811410.

[24] Tanizawa Y, Fujisawa T, and Nakamura Y. DFAST: a flexible prokaryotic genome annotation pipeline for faster genome publication. Bioinformatics, 34(6) 1037-1039, 2018.

[25] Bortolaia V, Kaas RS, Ruppe E, Roberts MC, Schwarz S, Cattoir V, Philippon A, Allesoe RL, Rebelo AR, Florensa AF, Fagelhauer L, Chakraborty T, Neumann B, Werner G, Bender JK, Stingl K, Nguyen M, Coppens J, Xavier BB, Malhotra-Kumar S, Westh H, Pinholt M, Anjum MF, Duggett NA, Kempf I, Nykäsenoja S, Olkkola S, Wieczorek K, Amaro A, Clemente L, Mossong J, Losch S, Ragimbeau C, Lund O, Aarestrup FM. ResFinder 4.0 for predictions of phenotypes from genotypes. J Antimicrob Chemother. 2020 Dec 1;75(12):3491-3500. doi: 10.1093/jac/dkaa345. PMID: 32780112; PMCID: PMC7662176.

[26] Zankari E, Allesøe R, Joensen KG, Cavaco LM, Lund O, Aarestrup FM. PointFinder: a novel web tool for WGS-based detection of antimicrobial resistance associated with chromosomal point mutations in bacterial pathogens. J Antimicrob Chemother. 2017 Oct 1;72(10):2764-2768. doi: 10.1093/jac/dkx217. PMID: 29091202; PMCID: PMC5890747.

[27] Jolley KA, Bray JE, Maiden MCJ. Open-access bacterial population genomics: BIGSdb software, the PubMLST.org website and their applications. Wellcome Open Res. 2018 Sep 24;3:124. doi: 10.12688/wellcomeopenres.14826.1. PMID: 30345391; PMCID: PMC6192448.

[28] Curran B, Jonas D, Grundmann H, Pitt T, Dowson CG. Development of a multilocus sequence typing scheme for the opportunistic pathogen Pseudomonas aeruginosa. J Clin Microbiol. 2004;42(12):5644-5649. doi:10.1128/JCM.42.12.5644-5649.2004

[29] World Health Organization. Antimicrobial resistance: global report on surveillance. 2014. Available at: http://www.who.int/drugresistance/documents/surveillancereport/en/. Accessed 14 January 2016.

[30] Horcajada JP, Montero M, Oliver A, Sorli L, et al. Epidemiology and treatment of Multidrug-Resistant and Extensively Drug-Resistant Pseudomonas aeruginosa infections. Clinical Microbiology Reviews Aug 2019, 32 (4) e00031-19; DOI: 10.1128/CMR.00031-19

[31] Yayan J, Ghebremedhin B, Rasche K. Antibiotic Resistance of Pseudomonas aeruginosa in Pneumonia at a Single University Hospital Center in Germany over a 10-Year Period. PLoS One. 2015;10(10):e0139836. Published 2015 Oct 2. doi:10.1371/journal.pone.0139836

[32] CDC. Antibiotic Resistance Threats in the United States, 2019. Atlanta, GA: U.S. Department of Health and Human Services, CDC; 2019. 
[33] Abbara S, Pitsch A, Jochmans S, Hodjat K, Cherrier P, Monchi M, Vinsonneau C, Diamantis S. Impact of a multimodal strategy combining a new standard of care and restriction of carbapenems, fluoroquinolones and cephalosporins on antibiotic consumption and resistance of Pseudomonas aeruginosa in a French intensive care unit. Int J Antimicrob Agents. 2019 Apr;53(4):416-422. doi: 10.1016/j.ijantimicag.2018.12.001. Epub 2018 Dec 8. PMID: 30537533.

[34] Zeng L, Jin S. aph(3')-IIb, a gene encoding an aminoglycoside-modifying enzyme, is under the positive control of surrogate regulator HpaA. Antimicrob Agents Chemother. 2003;47(12):3867-3876. doi:10.1128/AAC.47.12.3867-3876.2003

[35] Hocquet D, Berthelot P, Roussel-Delvallez M, et al. Pseudomonas aeruginosa may accumulate drug resistance mechanisms without losing its ability to cause bloodstream infections. Antimicrob Agents Chemother. 2007;51(10):3531-3536. doi:10.1128/AAC.00503-07

[36] Michalska AD, Sacha PT, Ojdana D, Wieczorek A, Tryniszewska E. Prevalence of resistance to aminoglycosides and fluoroquinolones among Pseudomonas aeruginosa strains in a University Hospital in Northeastern Poland. Braz J Microbiol. 2015;45(4):1455-1458. Published 2015 Mar 4. doi:10.1590/s1517-83822014000400041

[37] Holbrook SYL, Garneau-Tsodikova S. Evaluation of Aminoglycoside and Carbapenem Resistance in a Collection of Drug-Resistant Pseudomonas aeruginosa Clinical Isolates. Microb Drug Resist. 2018;24(7):1020-1030. doi:10.1089/mdr.2017.0101

[38] Teixeira B, Rodulfo H, Carreño N, Guzmán M, Salazar E, De Donato M. Aminoglycoside resistance genes in Pseudomonas aeruginosa isolates from Cumana, Venezuela. Rev Inst Med Trop Sao Paulo. 2016;58:13. doi: 10.1590/S1678-9946201658013. Epub 2016 Mar 22. PMID: 27007556 ; PMCID: PMC4804550.

[39] Stoesser N, Batty EM, Eyre DW, et al. Predicting antimicrobial susceptibilities for Escherichia coli and Klebsiella pneumoniae isolates using whole genomic sequence data. J Antimicrob Chemother. 2013;68(10):2234-2244. doi:10.1093/jac/dkt180

[40] Sadouki Z, Day MR, Doumith M, Chattaway MA, Dallman TJ, Hopkins KL, Elson R, Woodford N, Godbole G, Jenkins C. Comparison of phenotypic and WGS-derived antimicrobial resistance profiles of Shigella sonnei isolated from cases of diarrhoeal disease in England and Wales, 2015. J Antimicrob Chemother. 2017 Sep 1;72(9):2496-2502. doi: 10.1093/jac/dkx170. PMID: 28591819.

[41] Owen JR, Noyes N, Young AE, et al. Whole-Genome Sequencing and Concordance Between Antimicrobial Susceptibility Genotypes and Phenotypes of Bacterial Isolates Associated with Bovine Respiratory Disease. G3 (Bethesda). 2017;7(9):3059-3071. Published 2017 Sep 7. doi:10.1534/g3.117.1137

[42] de Oliveira Santos IC, Albano RM, Asensi MD, D'Alincourt Carvalho-Assef AP. Draft genome sequence of KPC-2-producing Pseudomonas aeruginosa recovered from a bloodstream infection sample in Brazil. J Glob Antimicrob Resist. 2018 Dec;15:99-100. doi:

10.1016/j.jgar.2018.08.021. Epub 2018 Aug 30. PMID: 30172833. 
medRxiv preprint doi: https://doi.org/10.1101/2021.01.15.21249897; this version posted January 20, 2021. The copyright holder for this preprint (which was not certified by peer review) is the author/funder, who has granted medRxiv a license to display the preprint in perpetuity.

It is made available under a CC-BY-NC-ND 4.0 International license .

[43] Kocsis B, Toth A, Gulyas D, Ligeti B, Katona K, Rokusz L, Szabo D. Acquired qnrVC1 and blaNDM-1 resistance markers in an international high-risk Pseudomonas aeruginosa ST773 clone. J Med Microbiol. 2019 Mar;68(3):336-338. doi: 10.1099/jmm.0.000927. Epub 2019 Jan 22. PMID: 30667355.

[44] Madaha EL, Mienie C, Gonsu HK, et al. Whole-genome sequence of multi-drug resistant Pseudomonas aeruginosa strains UY1PSABAL and UY1PSABAL2 isolated from human broncho-alveolar lavage, Yaoundé, Cameroon. PLoS One. 2020;15(9):e0238390. Published 2020 Sep 4. doi:10.1371/journal.pone.0238390

[45] Freschi L, Bertelli C, Jeukens J, Moore MP, Kukavica-Ibrulj I, Emond-Rheault JG, Hamel J, Fothergill JL, Tucker NP, McClean S, Klockgether J, de Soyza A, Brinkman FSL, Levesque RC, Winstanley C. Genomic characterisation of an international Pseudomonas aeruginosa reference panel indicates that the two major groups draw upon distinct mobile gene pools. FEMS Microbiol Lett. 2018 Jul 1;365(14). doi: 10.1093/femsle/fny120. PMID: 29897457.

[46] Garneau-Tsodikova S, Labby KJ. Mechanisms of Resistance to Aminoglycoside Antibiotics: Overview and Perspectives. Medchemcomm. 2016 Jan 1;7(1):11-27. doi: 10.1039/C5MD00344J. Epub 2015 Sep 21. PMID: 26877861; PMCID: PMC4752126. 
medRxiv preprint doi: https://doi.org/10.1101/2021.01.15.21249897; this version posted January 20, 2021. The copyright holder for this preprint (which was not certified by peer review) is the author/funder, who has granted medRxiv a license to display the preprint in perpetuity.

It is made available under a CC-BY-NC-ND 4.0 International license.

\section{TABLES \& FIGURES}

Table 1. Susceptibility of P. aeruginosa isolates to antibiotics by time period.

\begin{tabular}{|c|c|c|c|c|c|}
\hline & & $\begin{array}{c}1999-2002 \\
n=93\end{array}$ & $\begin{array}{c}2003-2009 \\
n=101\end{array}$ & $\begin{array}{c}2017-2019 \\
n=33\end{array}$ & P-value \\
\hline \multirow[t]{2}{*}{$\begin{array}{l}\text { Piperacillin- } \\
\text { Tazobactam }\end{array}$} & Susc & 65 (70\%) & 75 (74\%) & 22 (67\%) & $p=0.32$ \\
\hline & NS & $28(30 \%)$ & $26(26 \%)$ & $6(18 \%)$ & \\
\hline \multirow[t]{2}{*}{ Cefepime } & Susc & $63(68 \%)$ & 85 (84\%) & 26 (79\%) & $p=0.19$ \\
\hline & NS & $24(26 \%)$ & $16(16 \%)$ & $7(21 \%)$ & \\
\hline \multirow[t]{2}{*}{ Meropenem } & Susc & $67(72 \%)$ & $63(62 \%)$ & 26 (79\%) & $p=0.96$ \\
\hline & NS & $25(27 \%)$ & $38(38 \%)$ & $7(21 \%)$ & \\
\hline \multirow[t]{2}{*}{ Ciprofloxacin } & Susc & $53(57 \%)$ & $61(60 \%)$ & $23(70 \%)$ & $p=0.23$ \\
\hline & NS & $40(43 \%)$ & $40(40 \%)$ & $10(30 \%)$ & \\
\hline \multirow[t]{2}{*}{ Amikacin } & Susc & 88 (95\%) & $93(92 \%)$ & 31 (94\%) & $p=0.93$ \\
\hline & NS & $5(5.4 \%)$ & $5(5.0 \%)$ & $2(6.1 \%)$ & \\
\hline \multirow[t]{2}{*}{ Tobramycin } & Susc & $81(87 \%)$ & 87 (86\%) & $28(85 \%)$ & $p=0.98$ \\
\hline & NS & $12(13 \%)$ & $14(14 \%)$ & $4(12 \%)$ & \\
\hline \multirow[t]{2}{*}{ Gentamicin } & Susc & $68(73 \%)$ & $88(87 \%)$ & $25(76 \%)$ & $p=0.16$ \\
\hline & NS & $25(27 \%)$ & $13(13 \%)$ & $7(21 \%)$ & \\
\hline \multirow[t]{2}{*}{ Colistin } & Susc & 86 (92\%) & 70 (69\%) & 27 (82\%) & $p<0.001$ \\
\hline & NS & $2(2.2 \%)$ & $30(30 \%)$ & $6(18 \%)$ & \\
\hline
\end{tabular}

$P$-values bolded indicate significance as calculated by Chi-Square test of linear trend. Susc

$=$ Susceptible; NS = Nonsusceptible. Not all numbers add up to the total number of isolates in each collection as testing data were unavailable for some isolates. 
medRxiv preprint doi: https://doi.org/10.1101/2021.01.15.21249897; this version posted January 20, 2021. The copyright holder for this preprint (which was not certified by peer review) is the author/funder, who has granted medRxiv a license to display the preprint in perpetuity.

It is made available under a CC-BY-NC-ND 4.0 International license.

Table 2. AME genes present in P. aeruginosa isolates.

\begin{tabular}{|c|c|c|c|c|}
\hline \multicolumn{5}{|c|}{ Number of Isolates with Gene (\% of Isolates) } \\
\hline & $\begin{array}{l}1999-2002 \\
(n=93)\end{array}$ & $\begin{array}{l}2003-2009 \\
(n=101)\end{array}$ & $\begin{array}{l}2017-2019 \\
(n=33)\end{array}$ & $\begin{array}{l}\text { Total } \\
(n=227)\end{array}$ \\
\hline$A A C(3)-I d$ & $1(1 \%)$ & $0(0 \%)$ & $0(0 \%)$ & $1(0.4 \%)$ \\
\hline$A A C(3)-111 b$ & $0(0 \%)$ & $2(2 \%)$ & $0(0 \%)$ & $2(0.9 \%)$ \\
\hline$A A C\left(6^{\prime}\right)-I b$ & $1(1 \%)$ & $3(3 \%)$ & $0(0 \%)$ & $4(2 \%)$ \\
\hline$A A C\left(6^{\prime}\right)-I b^{\prime}$ & $3(3 \%)$ & $0(0 \%)$ & $0(0 \%)$ & $3(1 \%)$ \\
\hline$A A C\left(6^{\prime}\right)-\| / C$ & $0(0 \%)$ & $1(1 \%)$ & $0(0 \%)$ & $1(0.4 \%)$ \\
\hline$A A C\left(6^{\prime}\right)-\| I$ & $1(1 \%)$ & $0(0 \%)$ & $0(0 \%)$ & $1(0.4 \%)$ \\
\hline $\operatorname{aad} A 1$ & $0(0 \%)$ & $2(2 \%)$ & $0(0 \%)$ & $2(0.9 \%)$ \\
\hline aadA10 & $4(4 \%)$ & $3(3 \%)$ & $1(3 \%)$ & $8(4 \%)$ \\
\hline $\operatorname{aadA2}$ & $4(4 \%)$ & $0(0 \%)$ & $0(0 \%)$ & $4(2 \%)$ \\
\hline aadA6 & $4(4 \%)$ & $5(5 \%)$ & $1(3 \%)$ & $10(4 \%)$ \\
\hline aadA7 & $0(0 \%)$ & $3(3 \%)$ & $0(0 \%)$ & $3(1 \%)$ \\
\hline ant(2')-la & $8(9 \%)$ & $4(4 \%)$ & $1(3 \%)$ & $13(6 \%)$ \\
\hline$a p h\left(3^{\prime}\right)-1 b$ & $0(0 \%)$ & $1(1 \%)$ & $0(0 \%)$ & $1(0.4 \%)$ \\
\hline$a p h\left(3^{\prime \prime}\right)-I b$ & $1(1 \%)$ & $0(0 \%)$ & $0(0 \%)$ & $1(0.4 \%)$ \\
\hline$a p h\left(3^{\prime}\right)-I / b$ & 93 (100\%) & $101(100 \%)$ & 33 (100\%) & $227(100 \%)$ \\
\hline$a p h(6)-l d$ & $1(1 \%)$ & $0(0 \%)$ & $0(0 \%)$ & $1(0.4 \%)$ \\
\hline $\begin{array}{l}\text { Isolates } \\
\text { with at least } \\
1 \mathrm{AME} \\
\text { gene* }\end{array}$ & $16(17 \%)$ & $14(14 \%)$ & $2(6 \%)$ & 32 (14\%) \\
\hline
\end{tabular}

*Excluding aph(3')-IIb. 
medRxiv preprint doi: https://doi.org/10.1101/2021.01.15.21249897; this version posted January 20, 2021. The copyright holder for this preprint (which was not certified by peer review) is the author/funder, who has granted medRxiv a license to display the preprint in perpetuity.

\section{It is made available under a CC-BY-NC-ND 4.0 International license .}

Figure 1. Susceptibility rates of $P$. aeruginosa isolates by antibiotic and time period.

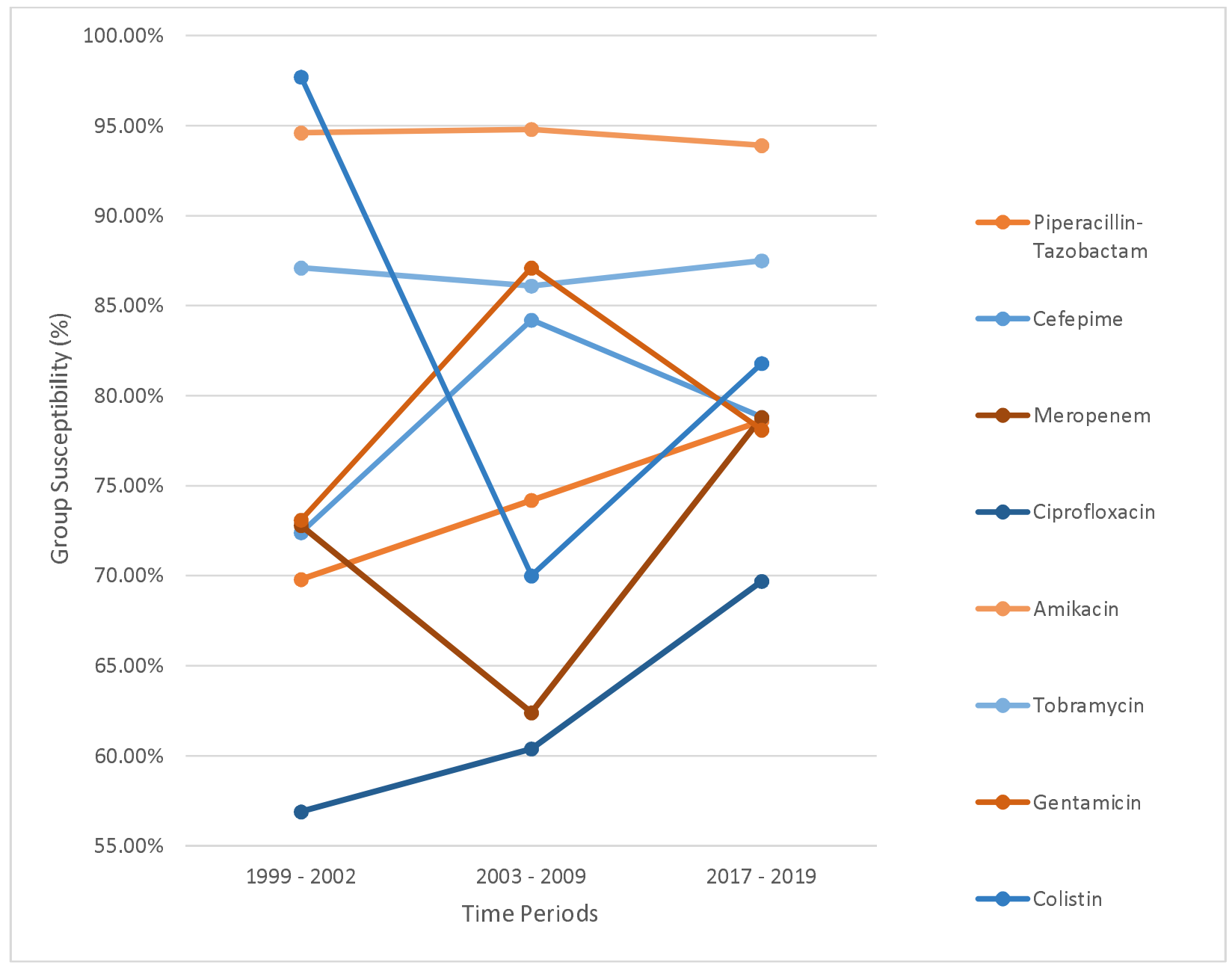


medRxiv preprint doi: https://doi.org/10.1101/2021.01.15.21249897; this version posted January 20, 2021. The copyright holder for this preprint (which was not certified by peer review) is the author/funder, who has granted medRxiv a license to display the preprint in perpetuity.

It is made available under a CC-BY-NC-ND 4.0 International license .

Figure 2. The context of AME genes present in PS1871. A. $\operatorname{ant}(2$ ')-Ia and $\operatorname{aadA1}$. B. AAC(6')$I b$ and $a a d A 1$. C. $a p h\left(3^{\prime}\right)-I I b$. Colors represent the following: red, AME genes; blue, genes conferring resistance to antiseptics and antibiotics other than aminoglycosides; yellow, transposition elements; green, other genes.

A.

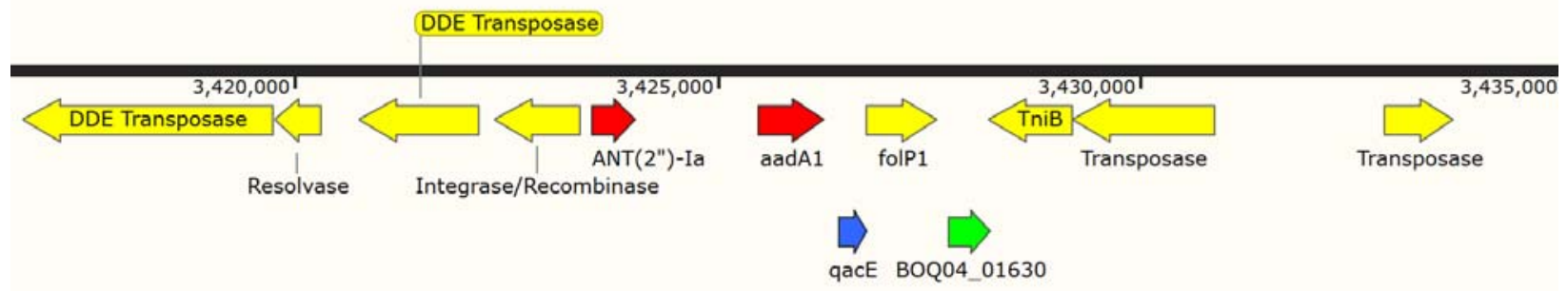

B.

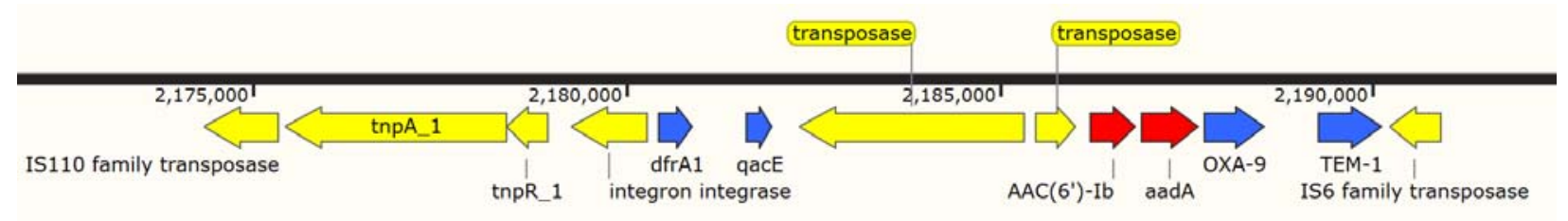

C.

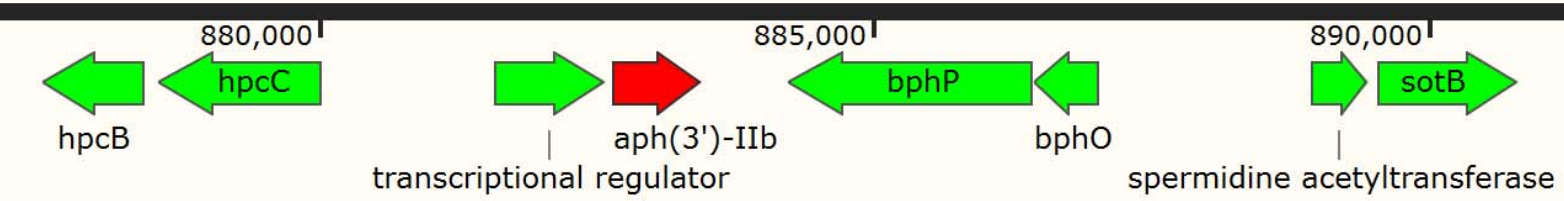

